University of Nebraska - Lincoln

DigitalCommons@University of Nebraska - Lincoln

Faculty Publications: Agricultural Economics

Agricultural Economics Department

2019

\title{
The opportunity cost of preserving the Brazilian Amazon forest.
}

Felipe de Figueiredo Silva

University of Nebraska-Lincoln, felipe.silva@huskers.unl.edu

Richard Perrin

University of Nebraska-Lincoln, rperrin@unl.edu

Lilyan E. Fulginiti

University of Nebraska, Ifulginiti1@unl.edu

Follow this and additional works at: https://digitalcommons.unl.edu/ageconfacpub

Part of the Agricultural and Resource Economics Commons

de Figueiredo Silva, Felipe; Perrin, Richard; and Fulginiti, Lilyan E., "The opportunity cost of preserving the Brazilian Amazon forest." (2019). Faculty Publications: Agricultural Economics. 163.

https://digitalcommons.unl.edu/ageconfacpub/163

This Article is brought to you for free and open access by the Agricultural Economics Department at DigitalCommons@University of Nebraska - Lincoln. It has been accepted for inclusion in Faculty Publications: Agricultural Economics by an authorized administrator of DigitalCommons@University of Nebraska - Lincoln. 


\title{
The opportunity cost of preserving the Brazilian Amazon forest
}

\author{
Felipe de Figueiredo Silva (corresponding author) \\ felipe.silva@huskers.unl.edu \\ University of Nebraska-Lincoln \\ Federal University of Viçosa
}

\section{Richard K. Perrin}

Jim Roberts Professor

rperrin@unl.edu

University of Nebraska-Lincoln

\section{Lilyan E. Fulginiti}

Roy Fredrick Professor

lfulginiti@unl.edu

University of Nebraska-Lincoln 


\title{
The opportunity cost of preserving the Brazilian Amazon forest
}

\begin{abstract}
We estimate the tradeoff between forest preservation and agricultural production for the Legal Amazon region, using census and deforestation data for municipalities in 2006. We use a directional distance function to represent the production possibility frontier, then calculate the shadow price of reducing deforestation in terms of agricultural income foregone. Results indicate that, on average, to preserve one hectare of forest, \$797 in annual agricultural GDP must be foregone. Using a discount rate of $10 \%$ and average forest carbon density of 132 tons per hectare, these results imply an average shadow price of $\$ 16$ per ton of $\mathrm{CO}_{2}$ permanently sequestered.
\end{abstract}

Key words: Amazon Forest, Agriculture, $\mathrm{CO}_{2}$ emissions, Deforestation, Trade-off. JEL: Q51, Q54, C61. 


\section{INTRODUCTION}

Agricultural expansion and deforestation are two of the major issues in worldwide climate change discussions due to their impacts on atmospheric $\mathrm{CO}_{2}$. Brazil encompasses the majority of the Amazon forest, and that portion constitutes $12 \%$ of the world's forest area and $59 \%$ of Brazil's surface (MacDicken et al., 2016). The Brazilian Amazon has been disappearing at the rate of 5 to 8 thousand $\mathrm{km}^{2}$ per year (National Institute for Space Research - INPE, 2018). The forest is important not only for carbon sequestration but it also provides benefits from other ecological and environmental services. All these considerations have led to the introduction of various forest conservation policies by the Brazilian government (Nepstad et. al. 2007).

The dramatic emissions levels and potential implications have led to a number of studies seeking to estimate the costs of reducing global carbon emissions by reducing deforestation in the Brazilian Amazon. The cost to the Brazilians of reducing deforestation consists primarily of the foregone rents from cattle and crop production and forgone sales of harvested forest products on the cleared land. Estimates of agricultural returns that must be foregone to sequester forest carbon for 30 years or more, reviewed later in this paper, range from $\$ 0.80$ to $\$ 21.02 / t$ of $\mathrm{CO}_{2}$ sequestered. Most of these studies proceed inductively, by basing their conclusions on budget estimates of the per-hectare returns from one or a combination of agricultural activities at one or more representative locations. These budget estimates are then combined in some fashion to estimate the foregone returns from any forest land in the region that is preserved rather than converted to agriculture. Income is assumed to continue being foregone for 30 years or more, as the forest is maintained. There are many sources of potential error in such an approach that might lead to inaccurate estimates of the foregone returns: the locations considered may not be 
representative, the budget estimates for agricultural activities at those locations may be inaccurate, and the set of activities may be incomplete or weighted inappropriately.

Given these potential weaknesses in previous estimates of agricultural income foregone from reduced deforestation, we introduce in this study a more deductive approach to complement the estimates obtained from these inductive approaches. We observe, across municipalities, how agricultural GDP (AGDP) changes when forests are converted, and from an econometric analysis of such data we estimate the tradeoffs between AGDP and forest preservation and thus the implied tradeoff between AGDP and carbon sequestered. Our approach provides novel and plausible estimates of the cost to Brazilian agriculture of reducing $\mathrm{CO}_{2}$ emissions by reducing deforestation. Our average estimate of $\$ 16 / t$ of $\mathrm{CO}_{2}(\$ 12 / \mathrm{t}$ median value) maintained in forest sequestration is higher than most previous opportunity cost estimates.

The range in previous estimates is due not only to different estimates of the annual earnings from deforested land, but also in part due to different assumptions about the period of years over which the income is to be foregone, different discount rates used for this period, and different assumptions regarding the average amount of carbon that is sequestered in the forests not converted. However, one can make ex-post adjustments to correct for different discount rates and length of time, and for different assumptions about carbon density, and we do so in this study for comparison purposes.

\section{DEFORESTATION AND AGRICULTURE IN THE BRAZILIAN AMAZON}

The Legal Amazon refers to an area that includes municipalities in the nine northern Brazilian states: Acre, Amazônia, Roraima, Rondônia, Amapá, Pará, Mato Grosso, Tocantins and Maranhão. This area has lower average GDP per capita than the rest of the country, and is 
heavily dependent on agriculture and forestry. Brazil participates in REDD+ (Reducing Emission from Deforestation and Forest Degradation), a clearing house for payment agreements for reducing deforestation established by Parties to the United Nations Framework Convention on Climate Change (UNFCCC) with the objective of preserving the forest, ameliorating climate change and conserving biodiversity. The Brazilian government uses a price (opportunity cost) of $\$ 5 / \mathrm{t} \mathrm{CO}$ for negotiating compensation for reducing deforestation through REDD+ assuming that a hectare of forest contains, on average, 132.2 tons of carbon ${ }^{1}$.

Grain and livestock expansion in this general region was accompanied by high rates of deforestation between 1995 and 2006 (Rivero et al., 2009). Several recent studies focus on land use change in Brazil in general and on the relationship between agriculture and deforestation in particular with the objective of estimating the opportunity cost of deforestation. Among these studies we find Reis and Guzmán (1992), Andersen et al. (2002), Mertens (2002), CavigliaHarris and Sills (2005), Vera-Diaz and Schwartzman (2005), Nepstad et al. (2007), Araujo et al. (2009), Börner et al. (2010), Bowman et al. (2012), Assunção, Gandour and Rocha (2013), Nepstad et al. (2014), Sills and Caviglia-Harris (2015) and Filho, Ribera and Horridge (2015). Rivero et al. (2009) and Margulis (2004) assert that livestock is the main driver of deforestation while Cardille and Foley (2003) suggest that livestock and crop production share the responsibility and that their relative contributions are not uniform across states. Nepstad et al. (2001) and Quintanilha and Lee Ho (2006) indicate timber harvesting as one of the main drivers. More recent analysis indicates that regulations have led to a decrease in deforestation. Interventions such as the Soy Moratorium (SoyM) in 2006, and the Cattle Agreement in 2010,

\footnotetext{
${ }^{1}$ The density for this region as averaged across estimates by Woods Hole Research Center (WHRC), NASA and Instituto de Pesquisa Ambiental da Amazonia (IPAM), is 131.6 t/ha.
} 
constituted obstacles to deforestation despite the fact that neither are enforced, but instead involve voluntary compliance (Nesptad et al., 2014; Gibbs et al., 2014). New regulations such as the Brazilian Forest Code (FC), the Rural Environmental Registry of private properties (CAR), along with surveillance by the Brazilian Institute of the Environment and Renewable Natural Resources (IB AMA), have also helped to control deforestation (De Souza Cunha et al. (2016), Pfaff et al. (2014, 2015a, 2015b), Gibbs et al. (2014), Soares-Filho et al. (2014), Hargrave and Kis-Katos (2013), De Sá et al. (2013), Pfaff and Robalino (2012)). Deforestation in the Brazilian Amazon did diminish after 2004, though may be again on the increase ${ }^{2}$. May, Millikan, and Gebara (2011) argue that contradictory policies have detracted from deforestation reduction targets.

Margulis (2004) estimates an opportunity cost of forest preservation of $\$ 137.99 /$ ha per year as the sum of the foregone revenue from agricultural activities. Vera-Diaz and Schwartzman (2005) used budget information from the literature to construct cash flows from deforested land for production of soy, timber and cattle and so estimate the cost of sequestering a ton of $\mathrm{CO}_{2}$ in the range from $\$ 0.80$ to $\$ 6.10$. Nepstad et al. (2007) estimated an average shadow price of $\$ 5.65 / t$ of carbon sequestered. Their findings are from spatially-explicit simulation models based on estimated rents from soybean production, cattle production and timber sales.

Börner and Wunder (2008) estimated relatively low opportunity costs for forest preservation, concluding that a price of $\$ 2.32 / \mathrm{t}$ of $\mathrm{CO}_{2}$ would be sufficient to compensate for foregone income on $40 \%$ of the projected deforestation (554,842 hectares) in the state of Mato Grosso and of $93 \%$ (525,094 hectares) in the state of Amazonas. They further estimate that a price of $\$ 12.36$ would be sufficient to compensate for income foregone from $100 \%$ of the projected deforestation.

\footnotetext{
${ }^{2}$ Deforestation in the Amazon region decreased from 27.8 thousand $\mathrm{km}^{2}$ in 2004 to about 4.6 thousand $\mathrm{km}^{2}$ in 2012 and then increased again to $7.9 \mathrm{~km}^{2}$ in 2016 (http://www.obt.inpe.br/prodes/dashboard/prodes-rates.html).
} 
More recently, Ickowitz, Sills and Sassi (2017) use survey information on household income from agriculture (crops and large livestock) of smallholders in five locations in Brazil (in villages in the states of Acre, Amapá, Mato Grosso and Pará) during the period of 2010-2012. Their opportunity cost estimates range from $\$ 142.42$ to $\$ 1,522.00 /$ ha (using an exchange rate of $\mathrm{R} \$$ $1.76=\mathrm{US} \$ 1.00$ ). Their 30 -year present value estimates convert to a range of $\$ 2.89$ to $\$ 21.02 / \mathrm{t}$ of $\mathrm{CO}_{2}$ sequestered.

To facilitate comparisons, we have adjusted the above estimates to reflect our assumptions of 132.2 tons of carbon per hectare and forest preservation in perpetuity with a discount rate of $10 \%^{3}$ as well as a foreign exchange rate of R $\$ 2.17=$ US\$ 1.00 used in our analysis. Margulis' (2004) opportunity cost translates to $\$ 2.84 / \mathrm{t}$ of $\mathrm{CO}_{2}$, Vera-Diaz and Schwartzman's (2005) to at most \$7.59, Nepstad et al.’s (2007) to \$1.08, Börner and Wunder’s (2008) to \$3.14 and Ickowitz, Sills and Sassi (2017) to a range from $\$ 2.42$ to $\$ 20.68$. Table A1 in the Online Appendix summarizes these results.

\section{THE MODEL}

The people of the Amazon are being asked to reduce deforestation in order to provide a global public good, less $\mathrm{CO}_{2}$ in the atmosphere. Our objective is to estimate the stream of income they give up by foregoing deforestation, which in general consists of returns from timber marketing and agricultural enterprises to follow. Our approach is to estimate the slope of the municipalitylevel production possibilities frontier (PPF) for two outputs, agricultural GDP and deforestation, given the resources available to the municipality. We consider deforestation, a proxy for $\mathrm{CO}_{2}$ emissions, to be an undesirable product that cannot be costlessly disposed of. This PPF slope

\footnotetext{
3 More details on these calculations are found in the Online Appendix.
} 
identifies the tradeoff of interest, the dollars of AGDP sacrificed for each additional hectare of deforestation foregone (alternatively, the additional dollars of AGDP gained from each additional hectare of deforestation). We convert this potential stream of income into cost per ton of $\mathrm{CO}_{2}$ sequestered using an estimate of the average quantity of carbon sequestered per hectare of forest.

Chung, Färe, and Grosskopf (1997) (CFG, hereafter) developed a theoretical structure to characterize technologies with both desirable and undesirable outputs, and used it to identify the tradeoffs between paper and pollutants in the pulp and paper industry. This approach has since been adapted and used by others, among them by Färe et al. (2005) to estimate tradeoffs between electricity production versus air pollution; by Badau, Färe and Gopinath (2016) to estimate tradeoffs between country-level GDP and $\mathrm{CO}_{2}$ emissions; and by Majiwa, Lee and Wilson (2018) to estimate agricultural productivity in sub-Saharan Africa when greenhouse gas emissions are present.

Our adaptation of the CFG model specifies a municipality-level technology that uses $k$ inputs represented by the vector $\boldsymbol{x}$ to produce a single desirable output $y$ (AGDP) and a single undesirable output, $b$ (deforestation). Following CFG, we use an output directional distance function ${ }^{4}$ to represent this output possibility set $P(\boldsymbol{x})$,

$$
\vec{D}_{o}\left(\boldsymbol{x}, y, b ; g_{y}, g_{b}\right)=\max _{\lambda}\left\{\lambda:\left(y+\lambda g_{y}, b-\lambda g_{b}\right) \in P(\boldsymbol{x})\right\}
$$

where $g_{y}$ and $g_{b}$ are the directions in the directional vector $\boldsymbol{g}=\left(g_{y},-g_{b}\right)$. This function is used to describe a multiple input-multiple output production set, just as a production function with arguments $y$ and $\boldsymbol{x}$ is used to describe a single output frontier. A directional distance function

\footnotetext{
${ }^{4}$ Non-parametric distance functions were used in Coelli and Rao (2005) and in Trindade and Fulginiti (2015). See the Online Appendix for more detail on the distance function.
} 
with $g_{y}=g_{b}=1$ is illustrated by the arrow in Figure 1, is used to describe the production possibility set for a given input set $\boldsymbol{x}$. All $(y, b)$ combinations inside the PPF of the output set $\mathrm{P}(\boldsymbol{x})$, such as output plan $J_{l}$, are characterized by their distance $\lambda$ from the PPF, measured in multiples of the ray $g$. All $(y, b)$ combinations on the PPF itself, and only those combinations, are characterized by distance $\lambda=0$. The directional distance function is non-negative in $(y, b)$, nonincreasing and strongly disposable in $y$, non-decreasing in $b$, and concave and jointly weakly disposable in $(y, b)$. This last property implies an upward-sloping region of the PPF where disposal of the undesirable output is costly in terms of desirable output that must be foregone if the undesirable output $b$ is to be reduced. It is this property that makes this approach attractive for us to model deforestation, ultimately in our analysis a proxy for $\mathrm{CO}_{2}$ emissions, as undesirable output.

The translation property of the directional distance function, analog to Shepard's multiplicative homogeneity in outputs property, implies that

$$
\vec{D}_{o}\left(\boldsymbol{x}, \boldsymbol{y}+\lambda g_{y}, \boldsymbol{b}-\lambda g_{b} ; g_{y},-g_{b}\right)=\vec{D}_{o}\left(\boldsymbol{x}, \boldsymbol{y}, \boldsymbol{b} ; g_{y},-g_{b}\right)-\lambda, \quad \lambda \in \Re
$$

This states that increasing desirable outputs by $\lambda g_{y}$ while decreasing undesirable outputs by $-\lambda g_{b}$ (along the ray from $J_{l}$ to $A$ in figure 1) is equivalent to subtracting the distance $\lambda$ from the original directional distance function. We mention it here because we use this property in the empirical implementation.

The slope of a production possibility frontier is the marginal rate of transformation (MRT). Under profit maximization, optimal allocation is achieved when the MRT is equal to the ratio of output prices ( $q / p$ in figure 1$)$. For two desirable outputs under strong disposability the MRT is negative. When undesirable outputs are considered, weak disposability is assumed and the MRT is positive in the vicinity of the preferred allocation. This scenario, represented at point $\mathrm{A}$ in 
figure 1, is expected to be observed if reducing the undesirable output involves disposal fees or requires a reduction in the desirable output. In our case a positive MRT implies that a reduction in deforestation can only be achieved by a reduction in agricultural GDP.

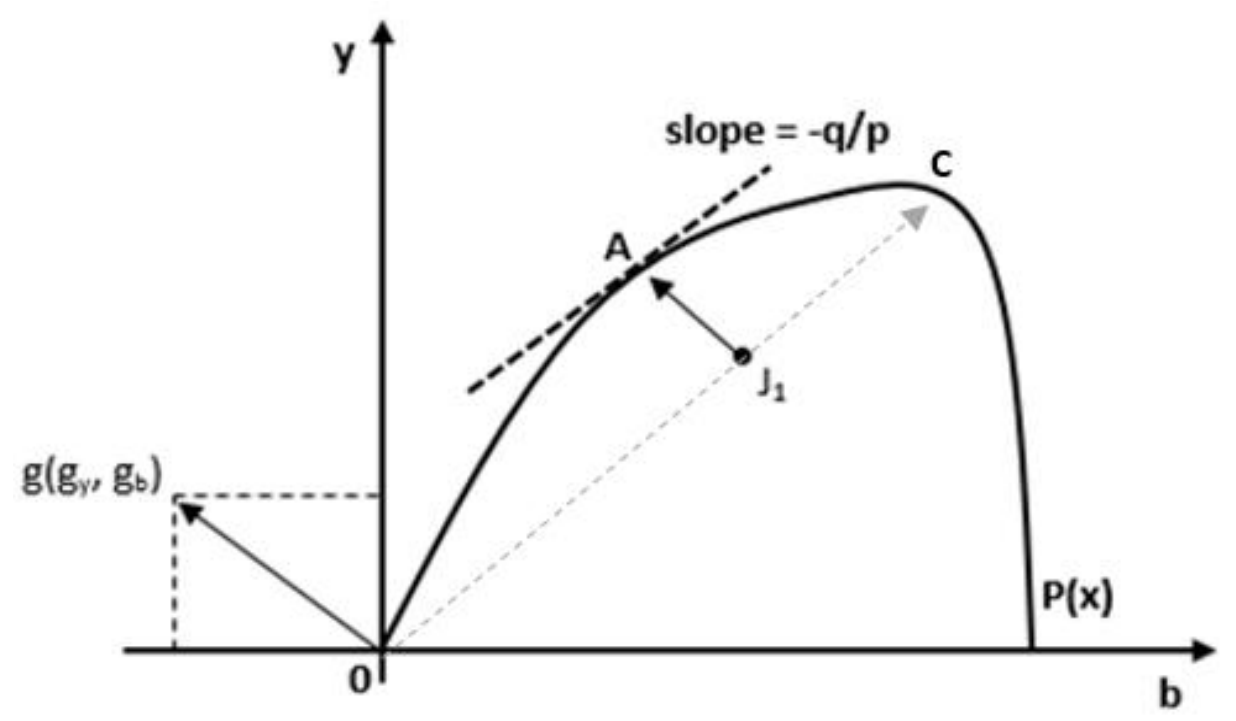

Figure 1. Output set - $P(x)$, and Directional Output Distance Function

Note: the scalars $q$ and $p$ represent price of undesirable and desirable outputs respectively.

Let $p$ and $q$ represent the prices of desirable and undesirable outputs. The dual relationship between the revenue function and the output distance function implies that the shadow price of the undesirable output $q$ is (Färe et al., 2005)

$$
q=-p\left[\frac{\partial \vec{D}_{o}(\boldsymbol{x}, y, b, \boldsymbol{g}) / \partial b}{\partial \vec{D}_{o}(\boldsymbol{x}, y, b, \boldsymbol{g}) / \partial y}\right]
$$

where $p$ is the known market price of the desirable output $y$. Equation (3) is the shadow price, or the opportunity cost of decreasing production of an undesirable output, evaluated at a given market price of a desirable output. Once the distance function $\vec{D}_{O}$ is estimated, equation (3) provides a dollar value of the desirable output forgone if the undesirable output is to be reduced 
by one unit. Expression (3) is non-negative given that the term in brackets is negative due to the monotonicity property of the distance function with respect to the desirable and undesirable outputs. We use this equation to infer the shadow price of forest preservation, and from that we approximate the shadow price of $\mathrm{CO}_{2}$ released by deforestation.

\section{DATA AND ESTIMATION}

For total AGDP and inputs at the municipality level for 590 municipalities, we use data from the Agricultural Census of 2006 (IBGE) for nine states; Amapá, Acre, Amazonas, Mato Grosso, Maranhão, Tocantins, Pará, Rondônia, and Roraima. This is the most recent reliable source of data for agricultural outputs and inputs. Deforestation was obtained from satellite data provided by the National Institute for Space Research (INPE). Descriptive statistics are in table 1. The Online Appendix presents more information on these variables.

Table 1. Descriptive Statistics for Agricultural Production, Inputs and Deforestation in 590 Municipalities in the Legal Amazon, Brazil, 2006.

\begin{tabular}{cccccc}
\hline Variable & Description & Mean & Std. Dev. & Min & Max \\
\hline$b_{1}$ & $\begin{array}{l}\text { Av. deforestation } \\
\text { 2004-06 (ha) }\end{array}$ & 3438.90 & 7917.37 & 0.00 & 108406.70 \\
$y_{1}$ & Ag. GDP (\$1000) & 8862.21 & 11224.85 & 410.47 & 119599.20 \\
$x_{1}$ & Capital (sum of equip. ${ }^{\text {a }}$ ) & 1637.64 & 1374.53 & 49.00 & 11283.00 \\
$x_{2}$ & Labor (sum of employees) & 3870.83 & 3776.78 & 126.00 & 39883.00 \\
$x_{3}$ & Irrigation (ha) & 415.08 & 1381.82 & 0.00 & 12850 \\
$x_{4}$ & Credit (\$1000) & 2449.30 & 12485.24 & 0.00 & 263341 \\
$z_{1}$ & Share of family owned farms & 0.86 & 0.13 & 0.03 & 1.00
\end{tabular}




\begin{tabular}{llccrr}
$z_{2}$ & $\begin{array}{l}\text { Total forest area in } 2006 \\
(\mathrm{~km} 2)\end{array}$ & 5190.67 & 13459.67 & 0.10 & 144093.00 \\
$z_{3}$ & $\begin{array}{l}\text { Total hydrological area in } \\
\text { 2005 (km2) }\end{array}$ & 184.07 & 480.06 & 0.00 & 4499.90 \\
\hline
\end{tabular}

Note: ${ }^{\text {a }}$ Capital is measured as the sum of equipment and the number of landowners in the municipality, see the text.

Margulis (2004) suggests that deforestation of a given plot might occur over three years, and yet be detected only in the third year of the process, depending on the process of deforestation used. It is possible that agricultural activities would be occurring during this period, with revenue from both agriculture and timber sales. This leads us to measure deforestation in 2006 as the average of that measured by INPE during the previous three years (2004-2006). The states of Roraima, Mato Grosso, Pará and Maranhão have higher absolute and per area measures of deforestation. Over three years, Mato Grosso and Pará each accounted for more than $30 \%$ of the total deforested area, jointly contributing $69 \%$ of what was deforested in this period.

Municipalities in the state of Mato Grosso had the largest average agricultural production in 2006, with an average AGDP of $\$ 15,992$ thousand dollars. This state was responsible for $39 \%$ of AGDP in the 590 municipalities considered in this research. Table A2 and figure A1 display the geographical distributions of 2006 AGDP and average deforestation during the three years from 2004 to 2006.

Inputs considered are labor, capital, land irrigated and credit. We are not able to develop a traditional index of capital because of data limitations in the agricultural census. As a proxy for capital, we follow Bragagnolo, Spolador and Barros (2010) and use the sum of the numbers of pieces of equipment reported and the number of landowners in the municipality. Also aiming to measure other inputs we include land irrigated in hectares and total credit used in the municipality. The currency adopted in this paper is dollars (US\$) shown in the text as \$. 
Monetary values in Brazilian currency (R\$ - Reais) are converted to U.S. dollars using an exchange rate of US\$ $1.00=\mathrm{R} \$ 2.17$.

\section{Estimation}

We approximate the distance function (Eq. 1) using a quadratic functional form, with the subscript $i=(1,2, \ldots, 590)$ for municipalities and $k=(1,2,3,4)$ for inputs

$$
\begin{aligned}
\vec{D}_{o_{i}}\left(\boldsymbol{x}_{\boldsymbol{i}}, y_{i}, b_{i} ; 1,-1\right)=\alpha_{0}+\sum_{k=1}^{4} \alpha_{k} x_{k i}+\frac{1}{2} \sum_{k=1}^{4} \sum_{l=1}^{4} \alpha_{k l} x_{k i} x_{l i}+\beta_{1} y_{i} \\
+\frac{1}{2} \beta_{11} y_{i} y_{i}+\theta_{1} b_{i}+\frac{1}{2} \theta_{11} b_{i} b_{i}+\mu_{11} y_{i} b_{i}+\sum_{k=1}^{4} \delta_{k m} x_{k i} y_{i}+\sum_{k=1}^{4} \varphi_{k r} x_{k i} b_{i}
\end{aligned}
$$

where $x_{k i}$ are labor, capital, irrigation and credit, $y_{i}$ is agricultural GDP, $b_{i}$ is deforestation, and $\alpha^{\prime} \mathrm{s}, \beta^{\prime} \mathrm{s}, \theta^{\prime} \mathrm{s}, \delta$ s,$\varphi^{\prime} \mathrm{s}$ and $\mu^{\prime} \mathrm{s}$ are parameters to be estimated. Following Färe et al. (2005) and others, we use the directional vector $\boldsymbol{g}=\left(g_{y},-g_{b}\right)=(1,-1)$, representing a simultaneous expansion of one dollar of AGDP and a contraction of one hectare of deforestation. This directional vector choice projects the unit $J_{l}$, in figure 1 , to a section of the frontier where the MRT is positive.

The symmetry and the translation properties in outputs are imposed before estimation, requiring the following restrictions

$$
\beta_{1}-\theta_{1}=-1, \quad \beta_{11}-\mu_{11}=0, \quad \theta_{11}-\mu_{11}=0, \quad \delta_{k 1}-\varphi_{k 1}=0
$$

where $k=(1,2, \ldots, 4)$ are inputs. Monotonicity and concavity were checked after estimation. We estimated equation (4) after imposing (4i) as 


$$
-\lambda_{i}=\vec{D}_{o_{i}}\left(x_{i}, y_{i}+\lambda_{i}, b_{i}-\lambda_{i} ; 1,-1\right)+\epsilon_{i}
$$

where $\lambda_{i}$ is the translation factor; in our case, $\lambda_{i}=b_{i}$ and $\epsilon_{i}$ is a composite error term. The quadratic functional form with symmetry and translation properties imposed is thus estimated as

$$
\begin{array}{r}
-b_{i}=\alpha_{0}+\sum_{k=1}^{4} \alpha_{k} x_{k i}+\frac{1}{2} \sum_{k=1}^{4} \sum_{l=1}^{4} \alpha_{k l} x_{k i} x_{l i}+\beta_{1} y_{i}^{\prime}+\frac{1}{2} \beta_{11} y_{i}^{\prime} y_{i}^{\prime}+\theta_{1} b_{i}^{\prime} \\
+\frac{1}{2} \theta_{11} b_{i}^{\prime} b^{\prime}{ }_{i}+\mu_{11} y_{i} b^{\prime}{ }_{i}+\sum_{k=1}^{4} \delta_{k m} x_{k i} y_{i}{ }_{i}+\sum_{k=1}^{4} \varphi_{k 1} x_{k i} b_{i}^{\prime}+\epsilon_{i}
\end{array}
$$

where the prime (') represents a variable normalized with respect to $\lambda_{i}$ that captures the translation property, $y_{i}^{\prime}=\left(y_{i}+\lambda_{i}\right)$ and $b_{i}^{\prime}=\left(b_{i}-\lambda_{i}\right), \lambda_{i}=b_{i}$. Desirable output $y_{i}^{\prime}$ is normalized agricultural GDP, $b_{\mathrm{i}}^{\prime}$ is normalized deforestation, and inputs $\boldsymbol{x}_{k i}$ are capital, labor, irrigation and credit. To estimate the parameters of equation (6) we use corrected ordinary least squares (COLS) and maximum likelihood (MLE) approaches and use the properties in (4i) to recover parameters dropped in estimation due to these properties. Following Färe et al. (2005), all variables in Equation (6) are normalized by their means ${ }^{5}$. Distances are thus measured in proportions of the mean output bundle.

Using equation (3) and given prices for the desirable output, $p$, the shadow price of an undesirable output in each municipality $i$ is:

$$
q_{b_{i}, y_{i}}=-p_{i}\left[\frac{\theta_{1}+\theta_{11} b_{i}+\sum_{k=1}^{4} \varphi_{k 1} x_{k i}+\mu_{11} y_{i}}{\beta_{1}+\beta_{11} y_{i}+\sum_{k=1}^{4} \delta_{k m} x_{k i}+\mu_{11} b_{i}}\right]
$$

\footnotetext{
${ }^{5}$ For a hypothetical municipality that uses mean inputs and produces mean outputs, the input and output variables would be $(x, y, b)=(1,1,-1)$. This implies that figure 1 is in normalized values. Thus observation $J_{I}$ (illustrated in figure 1) is expanded by $\lambda^{*} \bar{y}$, and contracted by $\lambda^{*} \bar{b}$ simultaneously.
} 
where there are $k=1, \ldots, 4$ inputs. Equation (7) is used in this study to estimate the shadow price in municipality $i$ of reducing deforestation by one hectare, expressed in terms of agricultural GDP foregone. Given that agricultural GDP is a monetary value, $p_{i}=1$.

Equation (6) was estimated using COLS and MLE with the COLS parameters were used as starting point for the MLE estimation. In the estimation of Equation (6) the composite error term is $\epsilon_{i}=v_{i}-u_{i}$, where $v_{i}$ represents a typical random error term and $u_{i}$ represents the distance from the frontier, also referred in the literature as inefficiency. We assume a half-normal distribution $\left(u_{i} \sim N^{+}\left(0, \sigma_{u}^{2}\right)\right)$ for the inefficiency term for the MLE, as described in Kumbhakar, Wang, and Horncastle (2015). The distribution of the efficiency term, specifically $\sigma_{u}^{2}$, is assumed to be a linear function of exogenous variables $\left(z_{i}\right)$. In this estimation the $z_{i}{ }^{\prime} s$ are forest area in 2006, hydrological area in 2005, and share of farms that are family owned. This error component represents factors associated with each municipality, beyond the inputs $(\boldsymbol{x})$ and outputs $(y, b)$ explicitly accounted for in the main structure of equation (6), that might lead to input-output combinations that deviate from those of the municipalities that are on the frontier. It reflects, in part, the heterogeneity in resource quality and other factors that affect production and deforestation across municipalities that are not explicitly modelled. The estimation was done using Stata 14 following the command sfmodel suggested by Kumbhakar, Wang, and Horncastle (2015) and sfcross suggested by Belotti et al. (2013).

\section{RESULTS AND DISCUSSION}

Parameters estimated in equation (6) are listed in the Online Appendix table A3. The COLS estimation resulted in eleven statistically significant parameters out of twenty one (excluding state dummies), while there are thirteen significant MLE parameters. The properties of 
monotonicity $^{6}$, and concavity ${ }^{7}$ were checked at each data point after estimation with the MLE estimates presenting fewer violations. A Likelihood Ratio test indicates that MLE estimates with a half-normal distribution for the one-sided error term are superior to the COLS estimates at the $1 \%$ level of significance. The analysis that follows is based on the MLE estimates.

An estimate of the distance of each municipality from the frontier is obtained from equation (6), and is interpreted as a measure of inefficiency. The average distance estimated for the region was 0.087 . This means that, on average, agricultural GDP could be expanded by $8.7 \%$ (an average of $\$ 771,000$ ) while simultaneously decreasing deforestation by $8.7 \%$ (an average of 299 hectares $)^{8}$. Because resources for any one municipality are not in fact identical to those of the others, the inefficiency estimates are at least in part an indicator of resource heterogeneity across these municipalities not captured by the variables included in our model.

Using equation (7) and the estimated parameters we calculate the estimated shadow price for each municipality. On average across municipalities, the MLE estimates indicate that in 2006, $\$ 797$ in agricultural GDP must be foregone to preserve one hectare of forest at the margin (i.e., to decrease deforestation by one hectare $)^{9}$. The geographic and frequency distributions of these estimates are displayed in figure A3.

\footnotetext{
${ }^{6}$ Only 6 out of 590 observations did not satisfy monotonicity on desirable output for both MLE and COLS while 3 out of 590 observations did not satisfy monotonicity in undesirable output for the MLE and four for COLS.

${ }^{7}$ The estimated directional distance satisfies the necessary condition for concavity in $(y, b)$ given that $\beta_{11}=\theta_{11}=$ $\mu_{11}$ associated with the variable $y^{2}$ in the estimation is negative (table A3).

${ }^{8}$ Coefficients of the $\mathrm{z}$ variables in Online Appendix Table A3 indicate that a larger forested area and a larger hydrological area were each associated with a smaller inefficiency estimate, while a larger share of family-owned farms was associated with a larger inefficiency estimate.

${ }^{9}$ As robustness check, we performed alternative estimations. First we used different proxies for capital in the MLE estimation, and second, we used a different econometric approach, the Generalized Method of Moments (GMM). The median shadow price obtained ranges from \$538 in the GMM estimation, to \$664 in the MLE estimation with alternative capital proxies, compared to $\$ 578$ in our preferred model. We prefer the MLE model, because it allows additional heterogeneity through the efficiency component of the error term. Shadow prices obtained from these alternative estimations are in the Online Appendix Table A4.
} 
The median shadow price is $\$ 578 /$ ha, as compared to the simple average of $\$ 797 / \mathrm{ha}$. We calculate that about $88 \%$ of the area that was deforested had an opportunity cost less than the simple average. The median present value of net revenue foregone to preserve a hectare of forest in perpetuity, using a discount rate of $10 \%$, is $\$ 5,778 /$ ha. Margulis (2004), using a more standard inductive approach and a $10 \%$ discount rate, estimates an average present value of $\$ 1,380$ per hectare preserved, Vera-Diaz and Schwartzman (2005), for a 30-year period at 10\%, estimate a range of $\$ 449$ to $\$ 3,465 /$ ha, while the more recent estimates of Ickowitz, Sills and Sassi (2017) range from $\$ 1,424$ to $\$ 15,220 /$ ha.

Table 2 indicates that municipalities in Mato Grosso, Roraima, Maranhão and Pará have higher shadow prices than municipalities in other states. These municipalities are located along the lower geographical boundary of the "arc of deforestation" region, where agriculture has been fast developing during the last decades, reflecting high returns from deforestation.

Table 2. Average Shadow Prices for Forest Preservation in Terms of Agricultural GDP Foregone (\$/ha), by State in the Legal Amazon, Brazil, 2006.

\begin{tabular}{lcccc}
\hline \multicolumn{4}{c}{ ShadowPrice def,gdp $(\$$ per ha $)$} \\
\hline Mean & $\begin{array}{c}\text { Standard } \\
\text { Deviation }\end{array}$ & Minimum & Maximum \\
\hline Acre & 553 & 57 & 436 & 690 \\
Amazonas & 603 & 117 & 309 & 932 \\
Amapá & 555 & 58 & 505 & 711 \\
Maranhão & 744 & 905 & 318 & 9951 \\
Mato Grosso & 1253 & 2312 & 127 & 17064 \\
Pará & 669 & 341 & 22 & 2749 \\
Rondônia & 616 & 264 & 197 & 2212
\end{tabular}




\begin{tabular}{lcccc} 
Roraima & 975 & 1420 & 490 & 6088 \\
Tocantins & 689 & 654 & 492 & 5664 \\
\hline Legal Amazon & $\mathbf{7 9 7}$ & $\mathbf{1 2 0 7}$ & $\mathbf{2 2}$ & $\mathbf{1 7 0 6 4}$ \\
\hline
\end{tabular}

The shadow price of carbon dioxide $\left(\mathrm{CO}_{2}\right)$ sequestration

We use the estimates above to approximate the shadow price of reducing $\mathrm{CO}_{2}$ emissions by reducing deforestation in the Legal Amazon. This is very relevant information for REDD+ contracts and if global markets for $\mathrm{CO}_{2}$ become more developed. We then compare our results with others in the literature (Vera-Diaz and Schwartzman (2005), Nepstad et al. (2007), Börner and Wunder (2008) and Ickowitz, Sills and Sassi (2017)) and with the $\mathrm{CO}_{2}$ price estimates used by the Brazilian Ministry of the Environment (MMA) ${ }^{10}$.

The Brazilian government estimates that on average, one hectare of Brazilian forest sequesters 132.2 tons of carbon (MMA, 2012; Amazon Fund, 2015 ${ }^{11}$ ). One ton of carbon is equivalent to 3.67 tons of $\mathrm{CO}_{2}$, therefore one average hectare of Brazilian forest sequesters 485.17 tons of $\mathrm{CO}_{2}$. Using this carbon intensity coefficient, our results imply an average shadow price of $\$ 1.64$ per ton of $\mathrm{CO}_{2}$ sequestered for one year (a median shadow price of $\$ 1.19 / \mathrm{t}$ ). To sequester a ton of $\mathrm{CO}_{2}$ indefinitely, an average loss of $\$ 1.64$ in agricultural GDP must be foregone every year,

\footnotetext{
${ }^{10}$ Technical note $\mathrm{N}^{\circ} 40$, Departamento de Politicas Para o Combate ao Desmatamento, Ministerio do Meio Ambiente (MMA/DPCD), 2012. This document discusses how much should be raised for the "Fundo Amazonia" to preserve the forest. With data from PRODES/INPE they estimate that US $\$ 2.5$ billion has to be raised in 2012 at US\$ 5.00 per ton of $\mathrm{CO}_{2}$ to decrease deforestation to zero.

${ }^{11}$ The Amazon Fund (2015) raises funds to preserve the forest using this carbon content based on estimates from the Technical Committee of the Amazon Fund (CTFA), but states that it is a conservative estimate considering that the carbon content in the Amazon Forest ranges from 130 tons of Carbon/ha to 320 tons of Carbon/ha. This report can be found at https://web.bndes.gov.br/bib/jspui/handle/1408/8503.
} 
which at the discount rate of $10 \%$, results in an average shadow price of $\$ 16.42 / \mathrm{t}$ of $\mathrm{CO}_{2}$

sequestered in perpetuity ${ }^{12}$. At a $5 \%$ discount rate, this present value would rise to $\$ 32 / t$ of $\mathrm{CO}_{2}$.

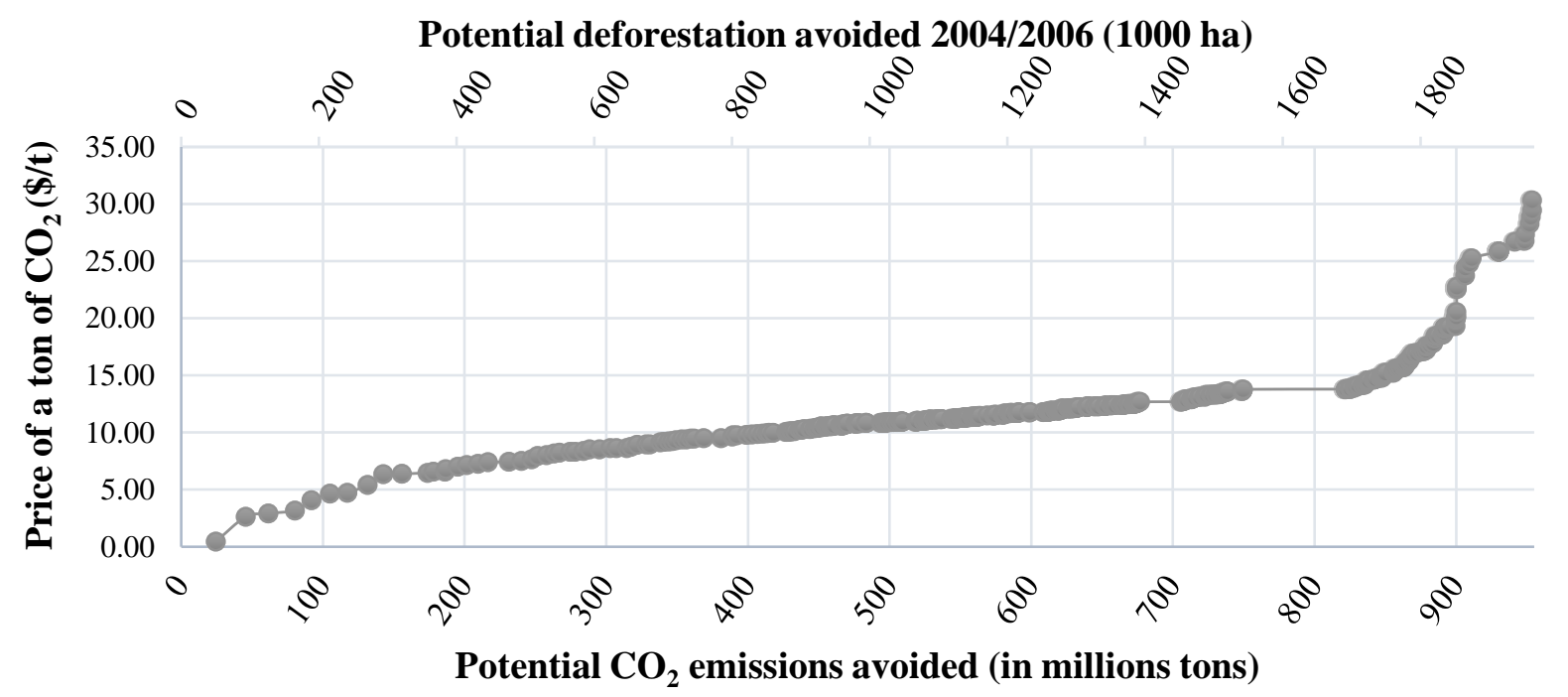

Figure 2. Supply of Carbon Sequestration (in million tons): Opportunity Cost of Carbon Sequestered in Forest that was Deforested in 2004/2006 (in 1000 hectares).

Note: The opportunity cost displayed in the vertical axis is in 2006 dollars. It is the present value of the cost of sequestering $\mathrm{CO}_{2}$ indefinitely, using a discount rate of $10 \%$ and a carbon content of 132.2 tons of carbon/ha of forest. The bottom horizontal axis was calculated using the top horizontal axis values and this carbon content. The top 5\% of the sample was dropped to simplify the figure.

Our estimates can also be used to obtain a supply of carbon sequestration, as shown in figure 2 . It indicates that at the price of $\$ 5.00$, used by the Amazon Fund to raise funds to preserve the forest, only about $10 \%$ of the $\mathrm{CO}_{2}$ emissions reductions would be compensated at or above their opportunity cost. A three-fold higher price (\$15/ton) would achieve adequate compensation for more than $70 \%$ of deforested lands. In contrast, Börner and Wunder (2008), estimate that a price

\footnotetext{
${ }^{12}$ Following a reviewer's suggestion we have recalculated this shadow price using the carbon stocks per state reported by the Instituto de Pesquisa Ambiental da Amazônia (IPAM) Calculadora de Carbono | Brazil http://www.carboncal.org.br/view/brasil/, accessed July 20 2018). Results are very similar. See the Online Appendix for more details.
} 
of $\$ 3.88 / t$ would be sufficient to compensate opportunity costs for projected deforestation of $1,414,000$ hectares just in the states of Mato Grosso and Amazonia, whereas our estimates are that this price ( $\$ 3.88 /$ ton) would adequately compensate less than 200,000 hectares in the larger region considered in this paper. Given the skewed distribution of our estimates across municipalities, we estimate that $86 \%$ of the municipalities have average shadow prices lower than the overall average of $\$ 16.42 / t$ of $\mathrm{CO}_{2}$. These municipalities represent $88 \%$ of the average deforestation that occurred during 2004-2006.

Our average estimated cost of $\$ 16.42$ per ton of $\mathrm{CO}_{2}$ sequestered ( $\$ 11.91 / \mathrm{t}$ median value) is much higher than the shadow price of $\$ 5.00 / t$ used by the Brazilian government to raise funds to preserve the forest through REDD+ (MMA, 2012; Amazon Fund, 2015). Our estimate is also higher than other estimates reported in the literature, for example the $\$ 0.80$ to $\$ 6.10 /$ ton estimate of Vera-Diaz and Schwartzman (2005) (\$1.53 to \$7.59 when adjusted to our assumptions for carbon content, discount rate and length of the period). Our figure is also much higher than the $\$ 1.54 /$ ton estimate of Nepstad et al. (2007) (\$1.08 when adjusted to our assumptions), even though the spatial distribution of their estimates (their figure 7) appears similar to what we present in figure A2. They find higher prices in the southeastern region of the Amazon Forest that include Mato Grosso, Roraima, Rondônia and Pará, up to $\$ 27.2 /$ of $\mathrm{CO}_{2}$, consistent with our high estimates of $\$ 25.86, \$ 20.10, \$ 12.71$ and $\$ 13.81 / \mathrm{t}$ of $\mathrm{CO}_{2}$, respectively for the same states. Our estimate of the average cost of sequestering a ton of $\mathrm{CO}_{2}$ does lie within the price range obtained by Ickowitz, Sills and Sassi (2017), for various areas within the Amazon. This range becomes $\$ 2.42 / \mathrm{t}$ to $\$ 20.68 / \mathrm{t}$ when adjusted to our assumptions.

What might explain these differences across studies in estimated net revenue streams from deforested land? Both Vera-Diaz and Schwartzman (2005) and Nepstad et al. (2007) considered 
a limited number of economic activities (grains, timber and ranching), relative to our consideration of all activities included in the agricultural GDP figures. Vera-Diaz and Schwartzman (2005) use an estimated average of 155 tons of carbon per ha rather than the 132.2 tons of carbon per ha we have used. At a $10 \%$ discount rate and a carbon content of 155 tons of carbon per ha as in their study, our estimated shadow price of $\mathrm{CO}_{2}$ would be $\$ 14.01 / \mathrm{t}$ rather than $\$ 16.42 /$ t. The latter study also considers estimates of 121 and 397 tons of carbon per ha. Using these coefficients our average estimate would range from $\$ 5.47 / \mathrm{t}$ to $\$ 17.95 / \mathrm{t}$. Ickowitz, Sills and Sassi (2017) use a 9\% discount rate and a carbon content that ranges from 145 to 221 . Our estimates would range from $\$ 10.92 / \mathrm{t}$ to $\$ 16.64 / \mathrm{t}$ under these assumptions.

The Amazon Fund (2015) notes that we can find in the literature a range of estimates of carbon density, from 130 tons of carbon per ha to 320 tons of carbon per ha. They have opted, in their contracts, for using 132.2 tons of carbon per ha to simplify their calculations. Using the 130-320 range of densities just mentioned, our shadow price estimate converts to a range of $\$ 6.79$ to $\$ 16.70$ per ton of $\mathrm{CO}_{2}$, closer at the lower bound to what others have estimated, but because of different assumptions about carbon density, rather than due to different estimates of income streams foregone.

\section{CONCLUSIONS}

The preservation of one hectare of the Amazon forest brings many benefits to the global public good, including carbon sequestration, habitat preservation, and others ${ }^{13}$. This article estimates the

\footnotetext{
${ }^{13}$ Ecosystem services from forest preservation include not only the provisioning of food but also of water; regulating services such as the control of climate and disease; supporting services, such as nutrient cycles and crop pollination; and cultural services, such as spiritual and recreational benefits. Except for those activities included in the AGDP, we have made no attempt to quantify the value of these services nor existence and option value.
} 
opportunity cost of that preservation, which is borne by Brazilians, in terms of the income stream foregone from a hectare of land if it had been preserved instead of deforested. We obtain this estimate, an average of $\$ 797 /$ ha, as the marginal rate of transformation between agricultural GDP and deforestation at the municipality level. We estimated this production possibilities frontier using census data for agriculture and satellite image data for deforestation, from 590 municipalities in 2006, using maximum likelihood estimation of a flexible quadratic specification of a directional distance function. This aggregate-level approach, not previously used, allows us to obtain estimates of the opportunity cost of preserving one hectare of forest to sequester $\mathrm{CO}_{2}$ using readily available aggregate data. It adds to the evidence on the true opportunity cost to Brazilians.

The estimated \$797/ha in average foregone annual earnings from forest preservation translates to a shadow price of $\$ 16 / \mathrm{t}$ of $\mathrm{CO}_{2}$ sequestered in perpetuity, using a social discount rate of $10 \%$ and an average carbon density of 132.2 tons per hectare of forest as in REDD+ contracts. The distribution of our estimates across municipalities is skewed, however, such that $70 \%$ of the estimated municipality shadow prices are lower than this average. The median shadow price is $\$ 577 /$ ha, or $\$ 12 / \mathrm{t}$ of $\mathrm{CO}_{2}$. Both the mean and the median estimates are higher than the $\$ 5.00 / \mathrm{t}$ used by the Amazon Fund to raise funds to preserve the forest, and higher than most of the estimates reported in the literature except for those in Ickowitz, Sills and Sassi (2017) who recently estimated prices that range from $\$ 2.42$ to $\$ 20.68 / \mathrm{t}$ of $\mathrm{CO}_{2}$, spanning the mean and median of our estimates.

Previous estimates of opportunity cost differ from ours primarily because of differences in the estimates of the income stream earned from deforested land. Those studies have been inductive in nature, in which per-hectare revenue streams from timber and specific agricultural enterprises 
are estimated mostly from budget data for a few locations, which are then assumed to represent the social tradeoff at the regional level. In contrast, we directly examine aggregate agricultural GDP and deforestation across 590 municipalities in the Amazon to estimate the marginal rate of transformation (the "tradeoff") between the two. Agricultural GDP includes revenues from all agricultural final products marketed. So conceptually it is an appropriate measure of how deforestation and aggregate agricultural income are related, at the margin. It is a more encompassing measure of earnings on deforested land than are farm-level earnings for a few enterprises, and it does not suffer from errors in constructing enterprise budgets that are intended to be representative. Hence our analytical approach provides useful alternative estimates of the opportunity cost of sequestering carbon in the Brazilian Amazon, that complement those from even recent inductive approaches such as in Ickowitz, Sills and Sassi (2017).

\section{REFERENCES}

Amazon Fund, 2015. Amazon Fund Activity Report 2015. The Brazilian Development Bank (BNDES), Ministry of Planning, Development and Management, and Ministry of the Environment.

Andersen, L. E., 2002. The dynamics of deforestation and economic growth in the Brazilian Amazon. Cambridge University Press.

Araujo, C., Bonjean, C. A., Combes, J.L., Motel, P. C., Reis, E. J., 2009. Property and deforestation in the Brazilian rights Amazon. Ecological Economics, 68(8): 2461-2468.

Assunção, J., C. Gandour, and R. Rocha, 2013. Deterring deforestation in the Brazilian Amazon: environmental monitoring and law enforcement. Climate Policy Initiative: PUC-Rio. 
Badau, F., R. Färe, Gopinath, M., 2016. Global resilience to climate change: Examining global economic and environmental performance resulting from a global carbon dioxide market. Resource and Energy Economics, 45: 46-64.

Belotti, F., Daidone, S., Ilardi, G., Atella, V., 2013. Stochastic frontier analysis using Stata. The Stata Journal, 13(4): 719-758.

Börner, J., Wunder, S., 2008. Paying for avoided deforestation in the Brazilian Amazon: from cost assessment to scheme design. International Forestry Review, 10(3): 496-511.

Börner, J., Wunder, S., Wertz-Kanounnikoff, S., M. R. Tito, L. Pereira, and N. Nascimento, 2010. Direct conservation payments in the Brazilian Amazon: Scope and equity implications. Ecological Economics, 69(6): 1272-1282.

Bowman, M. S., Soares-Filho, B. S., Merry, F. D., Nepstad, D. C., Rodrigues, H., Almeida, O. T., 2012. Persistence of cattle ranching in the Brazilian Amazon: a spatial analysis of the rationale for beef production. Land Use Policy, 29(3): 558-568.

Bragagnolo, C., Spolador, H. F.S., Barros, G. S. C., 2010. Regional Brazilian agriculture TFP analysis: A stochastic frontier analysis approach. Revista Economia, 11: 217-242.

Brazilian Institute of Geography and Statistics (Instituto Brasileiro De Geografia e Estatística IBGE). 2015. Data set. Available at http://www.ibge.gov.br/home/

Caviglia-Harris, J.L., Sills, E.O., 2005. Land use and income diversification: comparing traditional and colonist populations in the Brazilian Amazon. Agricultural Economics, 32(3): 221-237.

Cardille, J. A., Foley, J. A., 2003. Agricultural land-use change in Brazilian Amazonia between 1980 and 1995: Evidence from integrated satellite and census data. Remote Sensing of Environment, 87(4): 551-562. 
Chung, Y. H., Färe, R., Grosskopf, S., 1997. Productivity and undesirable outputs: a directional distance function approach. Journal of Environmental Management, 51(3): 229-240.

Coelli, T.J., Rao, D.S.P., 2005. Total factor productivity growth in agriculture: A Malmquist index analysis of 93 countries, 1980-2000. Agricultural Economics 32(1): 115-134.

De Sá, S.A., Palmer, C., Di Falco, S., 2013. Dynamics of indirect land-use change: empirical evidence from Brazil. Journal of Environmental Economics and Management, 65(3): 377-393.

de Souza Cunha, F.A.F., Börner, J., Wunder, S., Cosenza, C. A. N., Lucena, A., 2016. The implementation costs of forest conservation policies in Brazil. Ecological Economics, 130: 209-220.

Färe, R., Grosskopf, S., Noh, D., Weber, W., 2005. Characteristics of a polluting technology: theory and practice. Journal of Econometrics, 126(2): 469-492.

Filho, J. B. S.F., Ribera, L., Horridge, M., 2015 Deforestation control and agricultural supply in Brazil. American Journal of Agricultural Economics, 97(2): 589-601.

Gibbs, H. K., Rausch, L., Munger, J., Schelly, I., Morton, D. C., Noojipady, P., Soares-Filho, B., Barreto, P., Micol, L., Walker, N. F., 2015. Brazil's Soy Moratorium. Science, 347(6220): 377-378.

Hargrave, J., Kis-Katos, K., 2013. Economic causes of deforestation in the Brazilian Amazon: a panel data analysis for the 2000s. Environmental and Resource Economics, 54(4): 471-494.

Ickowitz, A., Sills, E., Sassi, C., 2017. Estimating Smallholder Opportunity Costs of REDD+: A Pantropical Analysis from Households to Carbon and Back. World Development , 95:15-26. Instituto de Pesquisa Ambiental da Amazônia (IPAM). CCAL (Calculadora de Carbono | Brazil. http://www.carboncal.org.br/view/brasil/, accessed July 202018. 
Kumbhakar, S., Wang, H., Horncastle, A., 2015. A practitioner's guide to stochastic frontier analysis using Stata. New York, NY, USA: Cambridge University Press.

MacDicken, K., Jonsson, Ö., Piña, L., Maulo, S., Contessa, V., Adikari, Y., Garzuglia, M., Lindquist, E., Reams, G., D’Annunzio, R., 2016. Global forest resources assessment 2015: how are the world's forests changing?. Second Edition, Food and Agricultural Organization of the United Nations. Available at http://www.fao.org/3/a-i4793e.pdf.

Majiwa, E., Lee, B, Wilson, C., 2018. Increasing agricultural productivity while reducing greenhouse gas emissions in sub-Saharan Africa: myth or reality? Agricultural Economics, 49 (2): 183-192.

Margulis, S, 2004. Causes of deforestation of the Brazilian Amazon. World Bank working paper; no. 22 .

May, P.H., Millikan, B., Gebara, M.F, 2011. The context of REDD+ in Brazil: Drivers, agents and institutions. Occasional paper 55: 2nd edition. CIFOR, Bogor, Indonesia.

Mertens, B., Poccard-Chapuis, R., Piketty, M.G., Lacques, A.E., Venturieri, A., 2002. Crossing spatial analyses and livestock economics to understand deforestation processes in the Brazilian Amazon: the case of Sao Felix do Xingu in South Para. Agricultural Economics, 27(3): 269-294.

Ministry of Environment (Ministerio do Meio Ambiente, Departamento de Politicas Pará o Combate ao Desmatamento - MMA/DPCD), 2012. Nota Técnica No. 40.

National Institute for Space Research (INPE/PRODES), 2018. Data on deforestation. Available at http://www.obt.inpe.br/prodes/index.php.

Nepstad, D., Soares-Filho, B., Merry, F., Moutinho, P., Rodrigues, H. O., Bownman, M., Schwartzman, S., Almeida, O., Rivero, S., 2007. The costs and benefits of reducing carbon 
emissions from deforestation and forest degradation in the Brazilian Amazon. In Conference: REDD, United Nations Framework Convention on Climate Change (UNFCCC), Conference of the Parties (COP), Thirteenth session 3-14 December 2007 Bali, Indonesia. Woods Hole Research Center.

Nepstad, D., McGrath, D., Stickler, C., Alencar, A., A., Swette, B., Bezerra, T., DiGiano, M., Shimada J., Motta, R.S, Armijo, E., 2014. Slowing Amazon deforestation through public policy and interventions in beef and soy supply chains. Science, 344(6188): 1118-1123.

Nepstad, D., Carvalho, G., Barros, A. C., Alencar, A., Capobianco, J. P., Bishop, J., Moutinho, P., Lefebvre, P., Silva, U. L., Prins, E., 2001. Road paving, fire regime feedbacks, and the future of Amazon forests. Forest Ecology and Management,154(3): 395-407.

Pfaff, A., Robalino, J., 2012. Protecting forests, biodiversity, and the climate: predicting policy impact to improve policy choice. Oxford Review of Economic Policy, 28(1): 164-179.

Pfaff, A., Robalino, J., Sandoval, C., Herrera, D., 2015b. Protected area types, strategies and impacts in Brazil's Amazon: public protected area strategies do not yield a consistent ranking of protected area types by impact. Phil. Trans. R. Soc. B, 370(1681): 20140273.

Pfaff, A., Robalino, J., Herrera, D., Sandoval, C., 2015a. Protected areas' impacts on Brazilian Amazon deforestation: examining conservation-development interactions to inform planning. PloS one, 10(7): e0129460.

Pfaff, A., Robalino, J., Lima, E., Sandoval, C., Herrera, L.D., 2014. Governance, location and avoided deforestation from protected areas: greater restrictions can have lower impact, due to differences in location. World Development, 55: 7-20.

Quintanilha, J.A., Lee Ho, L., 2006. A performance index developed by data envelopment analysis (DEA) to compare the efficiency of fire risk monitoring actions in municipalities of 
Brazilian Amazon region. In: Accuracy 2006: The Seventh International Symposium on Spatial Accuracy Assessment in Nat. Res. and Env. Sciences, Lisboa, Portugal.

Reis, E., Guzmán, R. M., 1992. An econometric model of Amazon deforestation. Texto Para Discussão no. 265. Institute for Applied Economic Research (IPEA). Available at http://repositorio.ipea.gov.br/bitstream/11058/4828/1/DiscussionPaper_34.pdf

Rivero, S., Almeida, O., Ávila, S., Oliveira, W., 2009. Pecuária e desmatamento: uma análise das principais causas diretas do desmatamento na Amazônia. Nova Economia, 19(1): 41-66.

Robalino, J., Pfaff, A., 2013. Ecopayments and deforestation in Costa Rica: A nationwide analysis of PSA's initial years. Land Economics, 89(3): 432-448.

Sills, E.O., Caviglia-Harris, J.L., 2015. Evaluating the long-term impacts of promoting "green" agriculture in the Amazon. Agricultural Economics, 46(S1): 83-102.

Soares-Filho, B., Rajão, R., Macedo, M., Carneiro, A., Costa, W., Coe, M., Rodrigues, H., Alencar, A., 2014. Cracking Brazil's forest code." Science, 344(6182): 363-364.

Trindade, F., Fulginiti, L., 2015. Is there a slowdown in agricultural productivity growth in South America? Agricultural Economics, 46(1): 69-81.

Vera-Diaz, M. C., Schwartzman, S., 2005. Carbon offsets and land use in the Brazilian Amazon. In Tropical deforestation and climate change / edited by Paulo Moutinho and Stephan Schwartzman. Instituto de Pesquisa Ambiental da Amazônia (IPAM) Belém/Pará Brazil; and Environmental Defense, Washington DC, USA. Available at https://www.edf.org/sites/default/files/4930_TropicalDeforestation_and_ClimateChange.pdf 